\title{
PALAEOMAGNETISM OF NEOPROTEROZOIC FORMATIONS IN THE VOLTA BASIN
}

\author{
F. BOUDZOUMOU, D. VANDAMME, P. AFFATON AND J. GATTACCECA
}

(Received 2 September 2009; Revision Accepted 26 January 2009)

\begin{abstract}
The Volta basin lies on the southern part of the West African craton, more precisely on the Leo (or Man) craton. The Dahomeyides chain is thrust onto its eastern fringe. The Volta basin is filled with Neoproterozoic to CambroOrdovician sediments. From bottom to top they are: the Boumbouaka Supergroup made of sandstone, microconglomerates, siltstones, shales and limestone lenses; the Pendjari or Oti Supergroup composed of a triad made of a diamictite, a cap carbonate and a silexitic complex that passes upwards to siltstones and shales; the Tamale Supergroup representing the molasse of the Dahomeyides chain. The three supergroups were sampled for palaeomagnetic study. The magnetic mineralogical study shows magnetite and hematite as carriers of magnetization. Mean palaeomagnetic directions are calculated on the high temperature components and yield a mean palaeopole, Plon $=349.3^{\circ}$, Plat $=44.1^{\circ}, \mathrm{dp}=26.6^{\circ}, \mathrm{dm}=33.7^{\circ}$, for formations with ages between $993 \pm 62 \mathrm{Ma}$ and $660 \pm 9 \mathrm{Ma}$ and a mean palaeopole, Plon $=119.5^{\circ}$, Plat $=71.2^{\circ}, \mathrm{dp}=19.8^{\circ}, \mathrm{dm}=38.1^{\circ}$, for sites dated between $635 \mathrm{Ma}$ and $600 \mathrm{Ma}$ which are, respectively, the ages of the marinoan glaciations in Volta basin and the Pan-African deformation, responsible of the Dahomeyides chain. The palaeolatitudes of the older formations about $44.9^{\circ} \mathrm{S}$ and that of the younger sites about $9.1^{\circ} \mathrm{S}$ show a migration of the West African craton from medium to low latitude during the Neoproterozoic, in conformity with the Snowball Earth hypothesis.
\end{abstract}

KEYWORDS: West African craton, Volta basin, Virtual Geomagnetic Pole, Palaeolatitude, Snowball Earth.

\section{INTRODUCTION}

The Volta basin is located in the southern part of the West African craton and stretches between longitudes $2^{\circ} \mathrm{W}$ and $3^{\circ} \mathrm{E}$ and latitudes 6 and $13^{\circ} \mathrm{N}$ (Fig. I). Its monoclinal western part grades eastwards to the folded external units of the Dahomeyides chain. The lithostratigraphy of the basin includes Neoproterozoic to Cambro-Ordivician sediments represented from bottom to top by the Boumbouaka, Oti and Tamale Supergroups which are separated by cartographic and/or erosional unconformities (Affaton, 1990). The base of the Middle Supergroup consists of a triad made of glaciogenic formations, cap carbonate and silexite that define a lithostratigraphic marker horizon in many basins on the West African craton. The glaciogenic formation in the Volta basin is considered the equivalent of that Jbeliat Group described in the Taoudeni basin situated in the north and attributed to the Marinoan glaciation (Deynoux et al., 2006).
In the Snowball Earth hypothesis (Kirschvink, 1992), the Sturtian and Marinoan glaciogenic formations are considered to be formed at low latitude (Hoffman et al., 1998). In order to constrain the palaeolatitude of formation of deposits in the Volta basin that include glacial sediments attributed to the Marinoan (Porter et al., 2004; Nedelec et al., 2007), seven sites were sampled for a palaeomagnetic study. Two sites, Boumbouaka 1 and 2 were located in the Boumbouaka Group of the Lower Supergroup. Four sites, Buipe, Koundjouare and Barkoissi 1 and 2 are attached to the triad of the Middle Supergroup. Buipe and Koundjouare belong to the cap carbonate of the glaciogenic formation and Barkoissi 1 and 2 to the horizon overlying the cap carbonate. The Kabalipe site is located in the Tamale Supergroup which constitutes the molasse of the Dahomeyides chain dated at Cambro-Ordovician.

F. Boudzoumou. Departement of Geology, Marien Ngouabi University, BP. 69, Brazzaville, Congo

D. Vandamme, CEREGE, Aix-Marseille University, CNRS, BP. 80, Europôle Mediterranean of Arbois, 13545 Aix-en-Provence Cedex 04, France

P. Affaton, CEREGE, Aix-Marseille University, CNRS, BP. 80, Europôle Mediterranean of Arbois, 13545 Aix-enProvence Cedex 04, France

J. Gattacceca, CEREGE, Aix-Marseille University, CNRS, BP. 80, Europôle Mediterranean of Arbois, 13545 Aix-en-Provence Cedex 04, France 


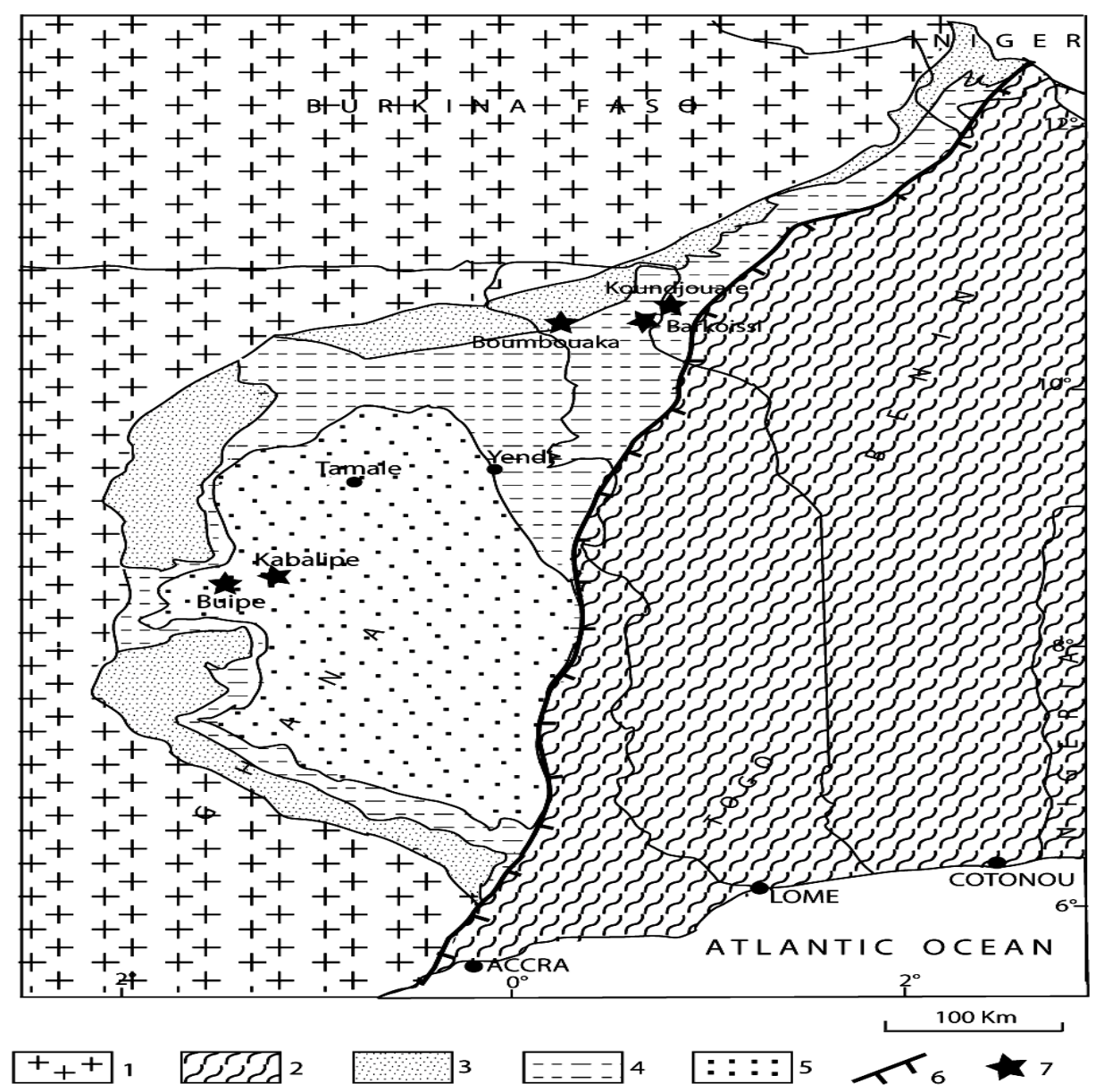

Fig. 1. Geological map of Volta Basin, after Affaton (1990), simplified.

1-Birimian basement; 2- Dahomeyides belt; 3-Boumbouaka Supergroup; 4- Oti Supergroup; 5-Tamale Supergroup; 6-Thrust contact; 7-Location.

\section{GEOLOGY OF THE VOLTA BASIN}

\section{Lithostratigraphy}

The lithostratigraphy of the Volta basin (Fig. 2) consists of three supergroups separated by unconformities. The Boumbouaka lower Supergroup, about $1000 \mathrm{~m}$ thick, starts with the Dapaong Group which is made of sandstone, micro-conglomerates, siltstones and shale. It passes upwards to the Fosseaux-Lions Group composed of conglomerates, microconglomeratic sandstone, shale and siltstones containing limestone lenses. At the upper part, the Mount Bombouaka Group (or Yembouré) is made of feldspathic sandstone, ferruginous sandstone containing silty and /or conglomeratic intercalations, siltstones and more or less ferruginous shale. The Fosse-aux-Lions ferruginous Group is dated by the Rb-Sr method on fine argillaceous fractions at $993 \pm 62 \mathrm{Ma}$ (Clauer, 1976). The Pendjari (or Oti or Afram) middle Supergroup, about 2500 to $4000 \mathrm{~m}$ thick, rests in cartographic and/or erosional unconformity pro-parte of glacial origin on the Boumbouaka Supergroup or directly on the Eburnean basement. It starts with the Sud-Bamboli Formation composed of glaciogenic sediments and cap carbonate and passes to the Barkoissi Formation made of clayey silexite containing intercalations of shale, siltstones and sometimes limestone. At the top, the Formation is made of siltstones and shales with intercalations of limestone lenses, sandstone or phospharenites and silexite bearing conglomerate. This Formation contains Chuaria Circularis, fossils of Vendian age (Amard and Affaton, 1984). It is dated by the $\mathrm{Rb}-\mathrm{Sr}$ method on fine illite fraction at $660 \pm 9 \mathrm{Ma}$ (Clauer, 1976). The Tamale upper Supergroup, about $500 \mathrm{~m}$ thick, rests in angular unconformity on the Pendjari Supergroup. It starts with the Yendi Group made up of conglomerates, shales and siltstones. At the upper part, the Kebia Group is composed of diamictites, polygenic conglomerate and sandstones passing upwards to micaceous sandstones, shales and siltstones then to finely bedded sandstones with intercalations of shales and massive feldspathic sandstones. This supergroup which represents the molasse filling the basin results from the active erosion of the adjacent Dahomeyides chain (Affaton, 1990). It is of Cambro-Ordovician age.

\section{Petrography}

The studied specimens included clastic rocks and non clastic rocks (Fig. 3). The clastic rocks of Boumbouaka 1 and 2 are made of fine grained 
sandstones to siltites (ph. A). Quartz is the dominant mineral. Feldspars and micas are present in very small amount. The quartz and feldspar grains are sub-angular to sub-blunt. The cement is made of sparitic carbonate. It is abundant in some samples which can be classified as sandy carbonates. Grains of iron oxides are frequent. The carbonate rocks described are from the Buipe and Koundjouare display micritic to microsparitic limestone facies which have parallel or locally discordant laminae. These laminae are formed by an alternation of horizons with and without peloids (ph. B). The samples also show horizons (levels) containing needles and stars of epigenized gypsum and also of detrital quartz (ph. C).
Keystone-vugs or geodes, empty or infilled with microsparite or sparite, that is sometimes associated with quartz, are present in places (ph. B). Facies with algal mat structures appear in some samples (ph. D). These algal levels can alternate with peloids bearing levels. Lithoclasts and probably bioclasts bearing limestone facies and rare quartz and feldspar clastic grains are present. They are cemented by microsparite or sparite (ph. E and F). The lithoclasts can be micritic or recrystallized into sparite. Fibrous calcite generally, fills fissures observed in some samples. Styloliths are accompanied by iron oxide (ph. F).

VOLTA BASIN

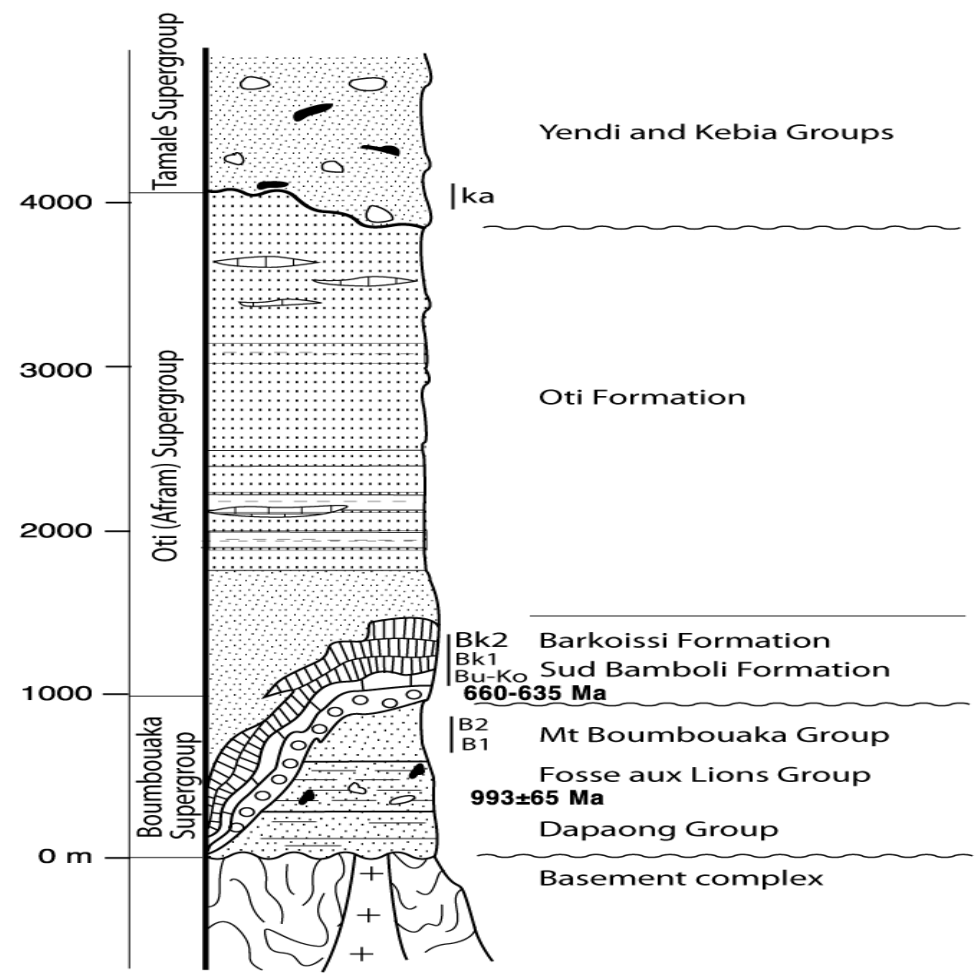

Fig. 2. Simplified lithostratigraphy of Volta basin, after Affaton (1990) Locations: B1-Boumbouaka 1; B2-Boumbouaka 2; Bu-Buipe; Ko-Koundjouare: BK1-Barkoissi 1; Bk2- Barkoissi 2; Ka-Kabalipe

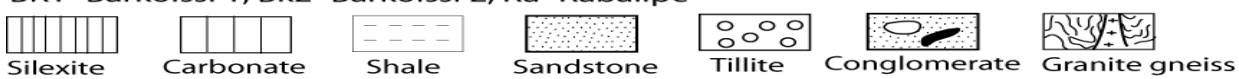

\section{PALAEOMAGNETISM}

Eighty three core samples made of sandstones, carbonates and silexites were taken at 7 sites (Boumbouaka 1 and 2, Buipe, Koundjouare, Barkoissi 1 and 2 and Kabalipe (Fig.1) and processed in the Geophysics and Planetology laboratory at the CEREGE (Aix-en-Provence, France).

\section{Method}

The samples were taken in the field using a portable petrol powered drill oriented with a solar or magnetic orienter and were cut in small cylindrical specimens $(2.5 \mathrm{~cm} \times 2.3 \mathrm{~cm})$ then stored in a nonmagnetic chamber in which the measures of magnetization were taken. Samples were subjected to thermal demagnetization in order to isolate the Characteristic Remanent Magnetization (CRM). The magnetization of the silexite samples from the Barkoissi 1 and 2 sites was measured using a JR5 (Agico) continuous rotation magnetometer. That of the carbonates and sandstones from other sites was done with a SQUID (2G enterprises) cryogenic magnetometer. The directions of the Characteristic Remanent Magnetization (CRM) are determined by principal component analysis (Kirschvink, 1980) after selection of the linear segments on Zijderveld's (1967) orthogonal projection. The mean direction at each site was calculated using Fischer's (1953) statistics. The data were processed using Cogne's (2003) Paleomac 6.1 software. 

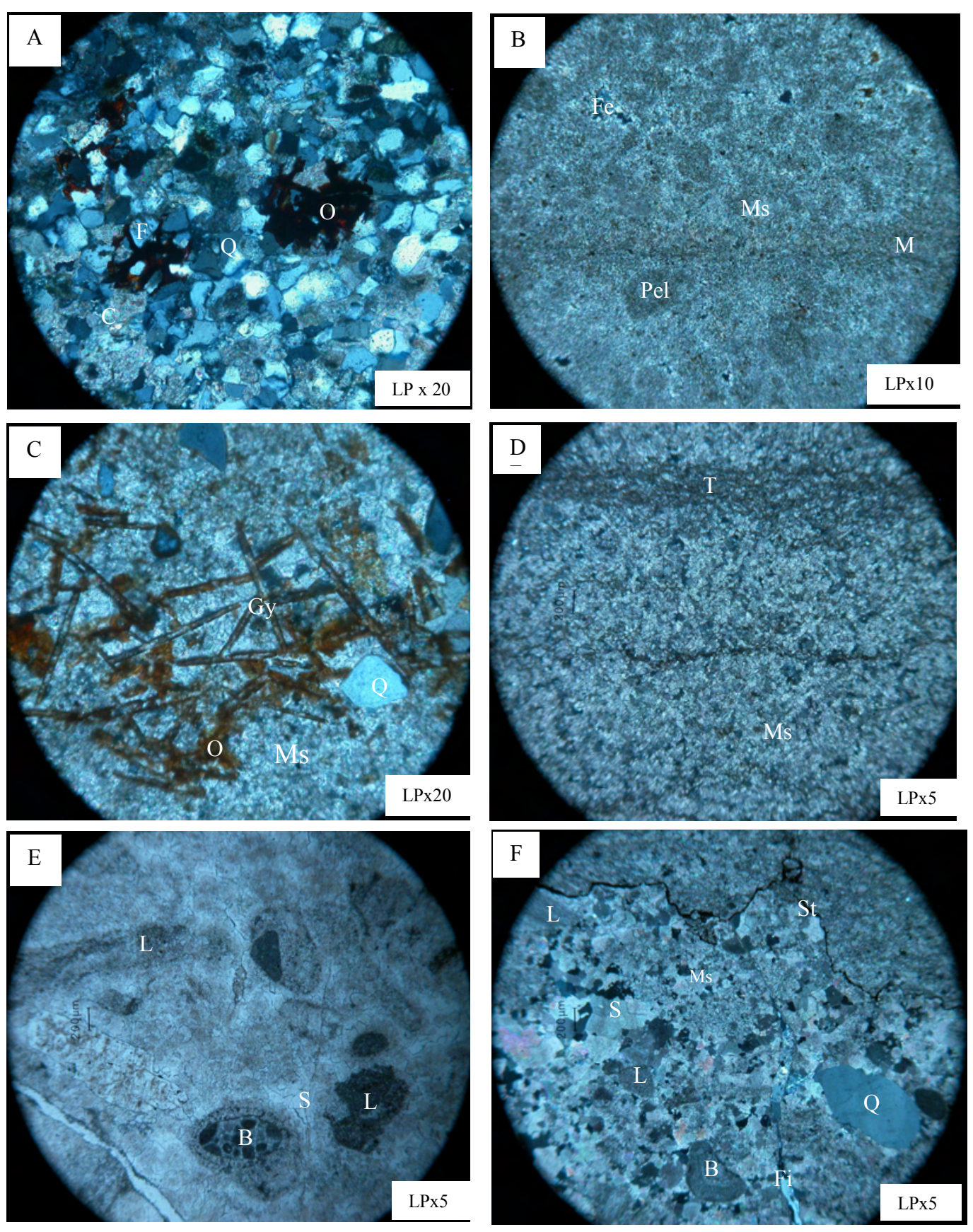

Fig. 3. Optical microscopic observations of Boumbouaka sandstones, Buipe and Koundjouare carbonates.

A: Boumbouaka sandstone; B-D: Buipe carbonate; E and F: Koundjouare carbonate. Q- quartz; F- feldspar; C-calcite; G- gypsum; O- iron oxide; S- sparite;

Ms- microsparite; M- micrite; Fe- fenestrae; Pe- peloid; T- algal mat; L- lithoclast; B- bioclast; Fi- fissure.

Three methods were used to determine the mineral carriers of magnetization. Two to three specimens from each site were subjected to thermomagnetic studies usiging an MFK1-MFA susceptibilimeter equipped with a CS3 furnace. The Lowrie's (1990) method was also used with application of fields $3 \mathrm{~T}, 0.4 \mathrm{~T}$, and $0.12 \mathrm{~T}$ respectively to three orthogonal axes of the sample. The acquisition of IRM by the samples was realized using an MMPMQ field pulse magnetizer. Finally, hysteresis 
cycles were produced using a micromag vibrating sample magnetometer (maximum field 1T).

\section{RESULTS}

The samples carry a Natural Remanent Magnetization (NRM) with intensity between 0.4 and $8.2 \times 10^{-3} \mathrm{~A} / \mathrm{m}$. The mean at each site is shown in Table I.

\section{Magnetic mineralogy}

\section{Thermomagnetism}

Nineteen samples, reduced to powder, were processed in argon and heated to temperatures of up to $670^{\circ} \mathrm{C}$ then cooled to room temperature. The results show a generally weak initial susceptibility signal situated between 0.3 and $14.1^{-10} \mathrm{~m}^{3}$. The curves obtained are either reversible (Fig. 4a) or irreversible (Fig. 4b). The irreversible curves show an increase in susceptibility between $400^{\circ}$ and $500^{\circ} \mathrm{C}$ during heating and about $580^{\circ} \mathrm{C}$ during cooling (Fig. 4b). Such an increase in susceptibility has been observed in the Gourma basin (Boudzoumou et al., submitted) and has no influence in the magnetization direction. Magnetite and hematite are indentified by the drop of the susceptibility respectively at $580^{\circ} \mathrm{C}$ (Fig. 4b) and at $650^{\circ} \mathrm{C}$ (Fig. 4a). a

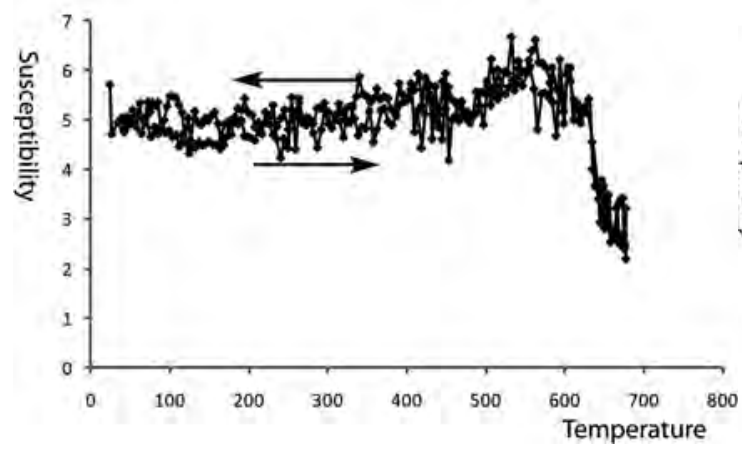

b

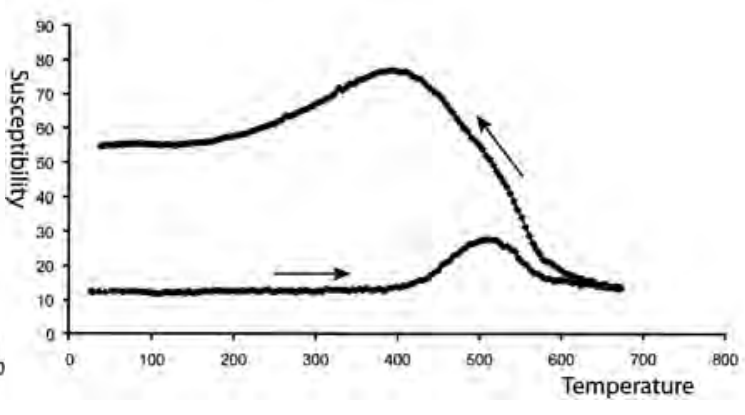

Fig. 4: Susceptibility / temperature curves of the specimens. Susceptibility is in $10^{-3}$

S.I; Temperature is in degrees Celsius a- Boumbouaka 2-08; b- Koundjouare 7156.

\section{Lowrie's test.}

Lowrie's (1990) test is applied to 9 samples. Depending on the sample, the highest intensity is carried by the hard (Fig. 5a, b), the medium (Fig. 5c) and the soft fraction (Fig. $5 \mathrm{~d}$ ). The release temperatures for the hard fraction lie between $650^{\circ} \mathrm{C}$ and $670^{\circ} \mathrm{C}$ Those for the medium fraction are, depending on the sample, situated at $575^{\circ} \mathrm{C}$ (Fig. $5 \mathrm{C}, \mathrm{d}$ ) and at $650^{\circ} \mathrm{C}$ (Fig. 5 a, b). The soft fraction shows a release temperature of $575^{\circ} \mathrm{C}$ (Fig. 5a-d). These release temperatures lie between $575^{\circ} \mathrm{C}$ and $670^{\circ} \mathrm{C}$ and are characteristic of magnetite and hematite minerals respectively.

\section{Hysteresis cycles}

The hysteresis cycles were realized on 9 samples subjected to a $1000 \mathrm{mT}$ field. The results reveal saturated and non-saturated magnetic minerals. The curves obtained, corrected for slope, are variable in shape (Fig. 6): (I) A normal shape (Fig. 6a); (2) A wasp shaped size (Fig. 6b) attributed to a bimodal distribution of the hard and soft coercive fractions that may be due to a difference in grain size of the same mineral or to different magnetic minerals (Raposo et al., 2003, 2006; Piper and Darabi, 2005) like magnetite and hematite; (3) The specimens show a largely open shape (Fig. 6c) that characterizes the presence of strong coercivity ferromagnetic grains such as hematite. 
$\mathrm{a}$

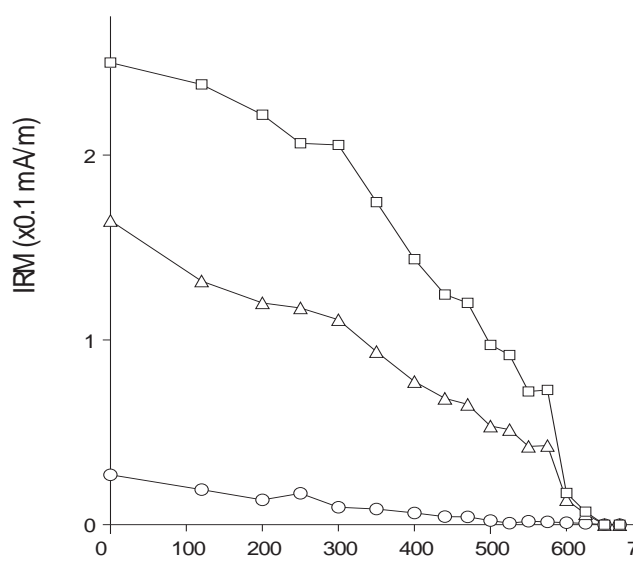

$\mathrm{c}$

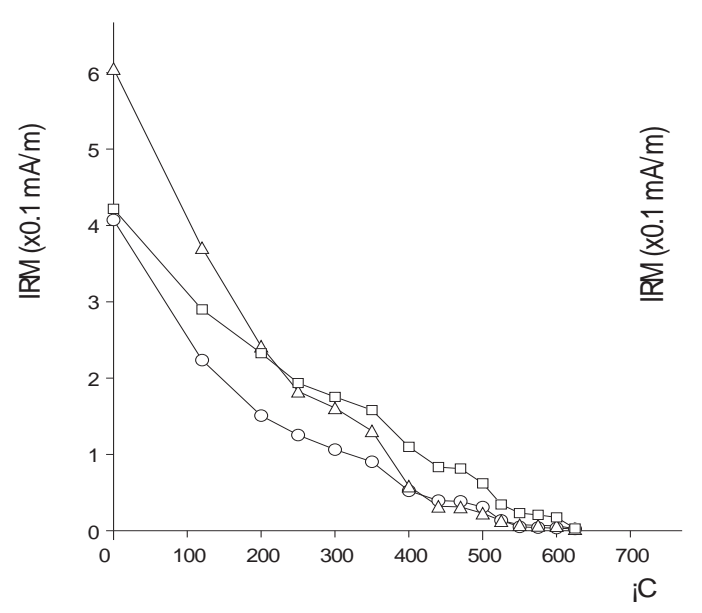

b

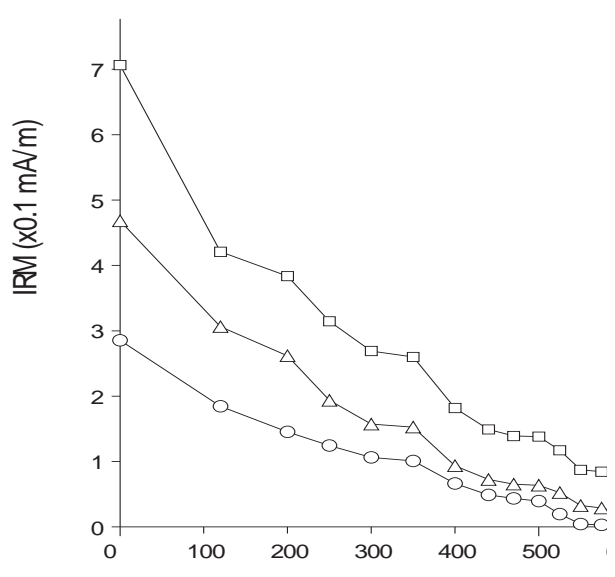

d

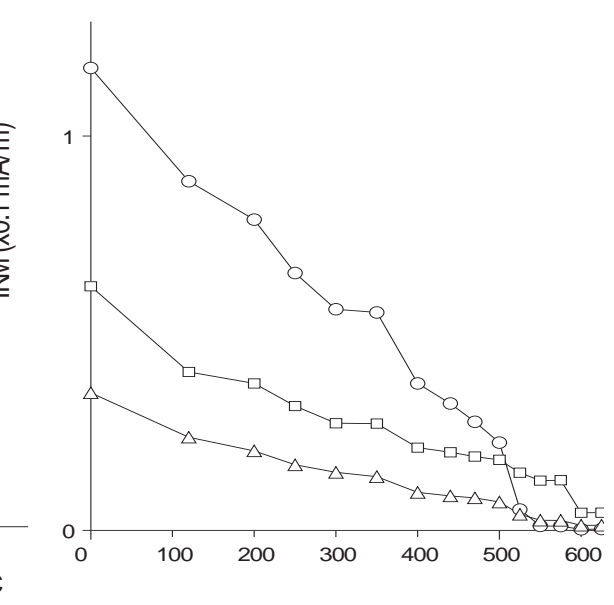

Fig. 5: Example of thermal demagnetization of three axes of isotherm remanent magnetization based on Lowrie (1990) method applied to some specimens. $\square$ : hard fraction; $\triangle$ : medium fraction; $O$ : soft fraction. (a) Buipe; (b) Boumbouaka 2 ;(c) Boumbouaka 1; (d) Buipe. 

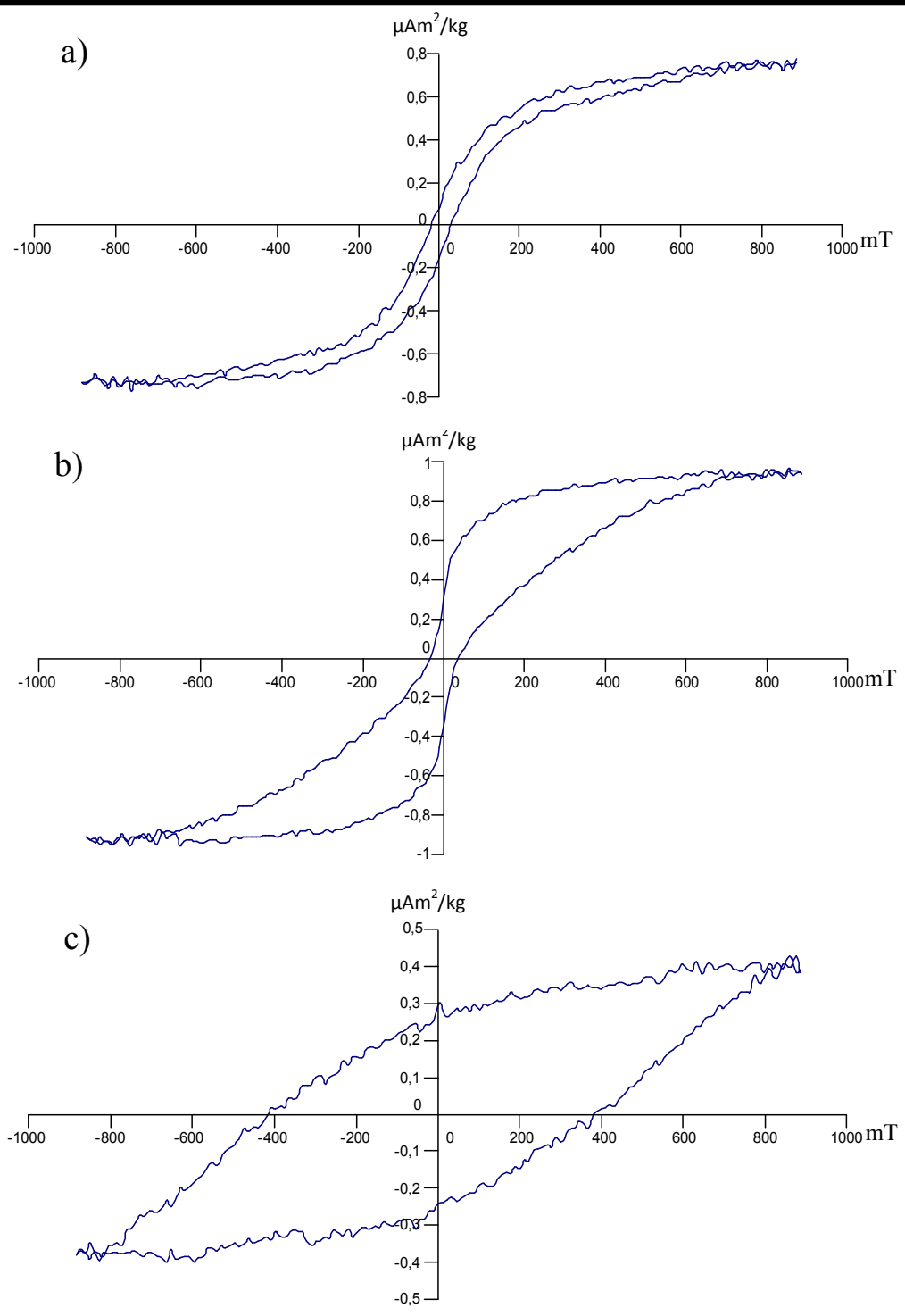

Fig. 6 : Hysteresis curves with dip correction of some specimens of the sites.

(a) Boumbouaka 01-04 ; (b) Barkoissi 01-04 ; (c) Barkoissi 02-01.

\section{PALAEOMAGNETIC DATA}

The thermal demagnetization curves indicate one to three principal components, carriers of magnetization. In the samples with one component, the latter is destroyed at temperatures, either of $575^{\circ} \mathrm{C}$ or of $670^{\circ} \mathrm{C}$ characteristic of magnetite and hematite respectively (Fig.7a). For the samples with two components (Fig. 7b), the first component is destroyed at $470^{\circ} \mathrm{C}$. It is a carrier of secondary magnetization. The second component is destroyed at $575^{\circ} \mathrm{C}$ or $670^{\circ} \mathrm{C}$. In the samples with three components, the first two components are destroyed at 300 and $470^{\circ} \mathrm{C}$ respectively. The last component is destroyed at $575^{\circ} \mathrm{C}$ or $670^{\circ} \mathrm{C}$. 

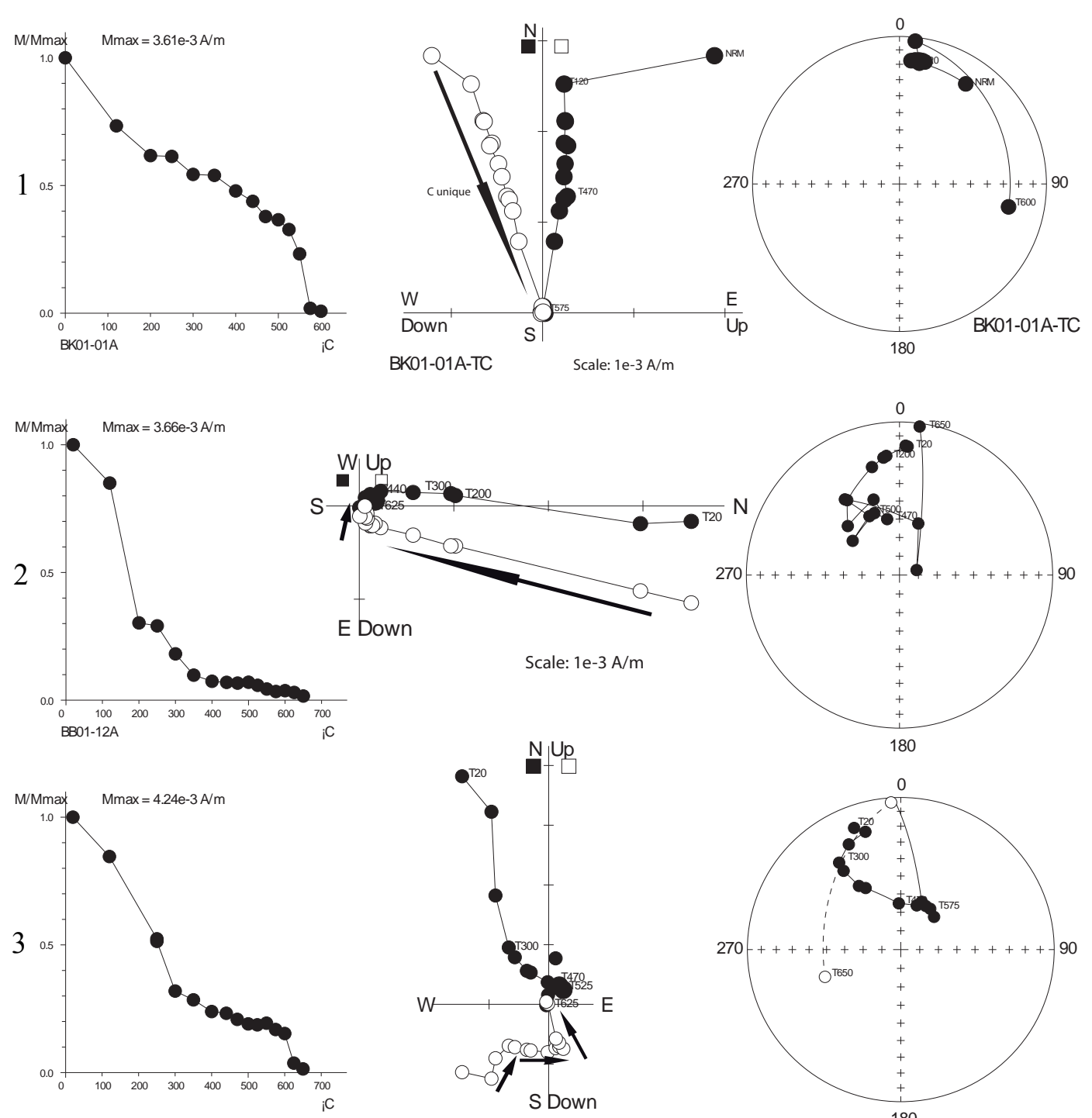

Scale: $1 \mathrm{e}-3 \mathrm{~A} / \mathrm{m}$

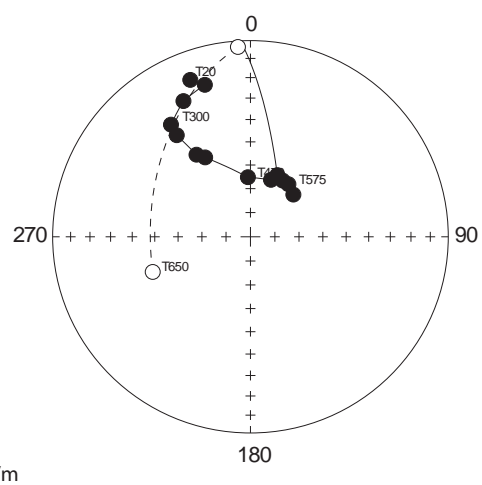

Fig.7. Thermal demagnetization of characteristic samples from Barkoissi 1 and Boumbouaka 1 sites. a) Intensity curves as a function of temperature; b) [Zijderveld's diagrams (The open/ full circles correspond to projections in the lower / upper hemisphere): $1 \mathrm{~b}$ - one component; $2 \mathrm{~b}$ - two components; $3 \mathrm{~b}$ - three components]; $\mathrm{c}$ ) Stereographic projections of demagnetization data.

\section{INTERPRETATION AND DISCUSSION}

\section{Interpretation}

The mean direction of the sites are calculated from the high temperature components $\left(500\right.$ to $575^{\circ} \mathrm{C}$ or 600 to $670^{\circ} \mathrm{C}$ ) that are susceptible to carry a primary magnetization. They are listed in Table I and shown (Fig. 8) after dip correction.

The Boumbouaka 1 and 2 sites are attached to the Boumbouaka Group of the Lower Supergroup (Fig. 2) which is dated between $993 \pm 65 \mathrm{Ma}, \mathrm{Rb}-\mathrm{Sr}$ age from underlying fine shale fractions 
Table 1: Mean directions of Volta basin sites.

\begin{tabular}{|c|c|c|c|c|c|c|c|c|c|c|c|c|c|c|c|c|}
\hline & \multirow[b]{3}{*}{$\underset{\left(10^{-3} \mathrm{~A} / \mathrm{m}\right)}{\mathrm{N} / \mathrm{n}} \underset{\mathrm{m}}{\mathrm{Jn}} \mathrm{Mx}$} & \multicolumn{8}{|c|}{ Palaeomagnetic directions } & \multicolumn{6}{|c|}{ Virtual Geomagnetic Poles } & \multirow[b]{3}{*}{ Plat } \\
\hline & & \multicolumn{4}{|c|}{ In situ } & \multicolumn{4}{|c|}{ After dip correction } & \multicolumn{2}{|c|}{ In situ } & \multicolumn{4}{|c|}{ After dip correction } & \\
\hline & & $\mathrm{D}$ & I & K & $\alpha_{95}$ & $\mathrm{D}$ & I & $\mathrm{K}$ & $\alpha_{95}$ & Lon & $\overrightarrow{\text { Lat }}$ & Lon & Lat & $\mathrm{dp}$ & $\mathrm{dm}$ & \\
\hline $\mathrm{Bb} 1$ & $10 / 148.2 \mathrm{~m}, \mathrm{~h}$ & 335.2 & 66.8 & 12.1 & 15.4 & 341.7 & 67.0 & 9 & 15.3 & 337.2 & 45.9 & 342.6 & 47.9 & 21.0 & 25.5 & 49. \\
\hline $\mathrm{Bb} 2$ & $12 / 165.2 \mathrm{~m}, \mathrm{~h}$ & 342.7 & 73.7 & 88.4 & 4.6 & 339.7 & 77.1 & 88.4 & 4.6 & 355.2 & 39.9 & 355.2 & 39.9 & 9.8 & 10.9 & 59.7 \\
\hline $\mathrm{Bu}$ & $6 / 250.4 \mathrm{~m}, \mathrm{~h}$ & 23.5 & -1.6 & 20.9 & 15.0 & 23.8 & 5.1 & 18.2 & 16.1 & 102.5 & 65.5 & 102.5 & 65.5 & 8.1 & 16.1 & 2.6 \\
\hline K & $8 / 120.6 \quad \mathrm{r}$ & 188.1 & 20.2 & 6.6 & 23.2 & 188.1 & 20.2 & 6.6 & 23.2 & 339.0 & -67.6 & 339.0 & -67.6 & 12.8 & 24.3 & 10.5 \\
\hline $\mathrm{Bk}$ & $4 / 9 \quad 1.4 \mathrm{~m}, \mathrm{~h}$ & .0 & 20.6 & 21.8 & 20.1 & 5.5 & 16.2 & 20.4 & 20.8 & 111.4 & 84.2 & 111.4 & 84.2 & 11.0 & 21.4 & 8.3 \\
\hline $\mathrm{Bk} 2$ & 6/7 $2.4 \mathrm{~m}, \mathrm{~h}$ & 18.3 & 19.3 & 25.8 & 13.4 & 17.0 & 17.1 & 21.3 & 14.8 & 94.6 & 73.2 & 94.6 & 73.2 & 7.9 & 15.3 & 8. \\
\hline
\end{tabular}

$\mathrm{N}$ : number of samples used in Fisher's calculation : $\mathrm{n}:$ number samples processed; $\mathrm{Jr}:$ natural remanent magnetization; $\quad M x$ : magnetic minerals ( $m=$ magnetite, $h=h e m a t i t e) ; D$ and $\mathrm{l}$ : declination and inclination ; $\mathrm{K}$ : precision parameter ; $\alpha_{95}$ : semi-angle of $95 \%$ confidence cone ; Lon/ Lat: Longitude/ Latitude of the VGP; dp/dm : semi axes at $95 \%$ confidence level ; Plat : palaeolatitude; Bb1: Boumbouaka 1; Bb2: Boumbouaka 2; Bu: Buipe; Ko: Koundjouare; Bk1: Rarknissi1: Rk7. Rarknissi ?:

(Clauer, 1976) and $660 \pm 9 \mathrm{Ma}, \mathrm{Rb}-\mathrm{Sr}$ age on illites from shale in the overlying Oti Formation (Clauer, 1976). The Boumbouaka site 1 yields the trend $D=341.7^{\circ}, I=67^{\circ}$, $\mathrm{k}=12.9, \quad \mathrm{\alpha}_{95}=15.3^{\circ}$ and the Boumbouaka 2 site, $\mathrm{D}=352.1^{\circ}, \mathrm{l}=74^{\circ}, \mathrm{k}=48.3, \mathrm{a}_{95}=6^{\circ}$ (Fig.8a,b). The Buipe and Koundjouare sites are stratigraphic equivalents and form the cap carbonate of the Marinoan diamictite that belongs to the triad at the base of the middle Supergroup (Fig. 2). The mean direction of Buipe is $\mathrm{D}=23.8^{\circ}, \mathrm{I}=5.1^{\circ}, \mathrm{k}=18.2, \quad \alpha_{95}=16.1^{\circ}, \quad$ (Fig. 8c). The average trend of Koundjouare, $D=188.1^{\circ}, \mathrm{I}=20.2^{\circ}, \mathrm{k}=6.6$, $a_{95}=23.2^{\circ}$, (Fig. 8d) is at the antipode of its stratigraphic equivalent Buipe. The Barkoissi 1 and 2 sites are attached to the silexites forming the upper member of the triad. The mean direction of Barkoissi $1, D=5.5^{\circ}$, $\mathrm{I}=16.2^{\circ}, \mathrm{k}=20.4, \alpha_{95}=20.8^{\circ}$, is close to the current field (Fig. 8e). That of Barkoissi 2 is $\mathrm{D}=17.0^{\circ}, \mathrm{I}=17.1^{\circ}$, $k=21.3, \quad a_{95}=14.8^{\circ}$ (Fig. 8f). Overlying all the sites described so far, is the Kabalipe one attached to the Tamale Supergroup. It consists of fluvio-glacial conglomerate dated Cambro-Ordovician and represents the molasse of the Dahomeyides chain. This site is used to perform the conglomerate test. The directions measured are those of the blocs. They show a dispersion of individual direction. This dispersion suggests that the conglomerate was not remagnetized after its formation. The conglomerate test is, in this case, positive, and thus confirms that the directions, obtained from the sites underlying the Kabalipe conglomerate, have not been remagnetized after the deposition of the conglomerate.

The mean direction obtained yield the Virtual Geomagnetic Poles (VGP) (Table I) presented on stereographic projection (Fig.9) with Africa Apparent Polar Wander Path (Besse and Coutillot 2002). The palaeopoles of Boumbouaka 1 and 2 yield, Plon $=342.6^{\circ}$, Plat $=47.9^{\circ}, \quad d p=21^{\circ}, \quad d m=25.5^{\circ}$ and Plon $=355.2^{\circ}$, Plat $=39.9^{\circ}, \mathrm{dp}=9.8^{\circ}, \mathrm{dm}=10.9^{\circ}$, respectively. The Buipe and Koundjouare (this latter brought to its antipode) poles are located in the NE quadrant and give, Plon $=102.5^{\circ}, \quad$ Plat $=65.5^{\circ}, \quad \mathrm{dp}=8.1^{\circ}, \quad \mathrm{dm}=16.1^{\circ}$ and Plon $=159^{\circ}, \quad$ Plat $=67.6^{\circ}, \quad d p=12.8^{\circ}$ and $d m=24.3^{\circ}$, respectively. The palaeopoles of Barkoissi 1 and 2 joints those of the underlying formations of Buipe and Koundjouare. The VGP of Barkoissi1 is Plon $=111.4^{\circ}$, Plat $=84.2^{\circ}, \mathrm{dp}=11^{\circ}, \mathrm{dm}=21.4^{\circ}$ while Barkoissi 2 gives, Plon $=94.6^{\circ}, \quad$ Plat $=73.2^{\circ}, \mathrm{dp}=7.9^{\circ}, \mathrm{dm}=15.3^{\circ}$. The palaeolatitudes of the Boumbouaka 1 and 2 sites have high values situated at $49.6^{\circ} \mathrm{S}$ and $59.7^{\circ} \mathrm{S}$ respectively. On the contrary, those of the other sites, Buipe, Koundjouare, Barkoissi 1 and 2, yield low values between $2.6^{\circ} \mathrm{S}$ and $10.5^{\circ} \mathrm{S}$. 

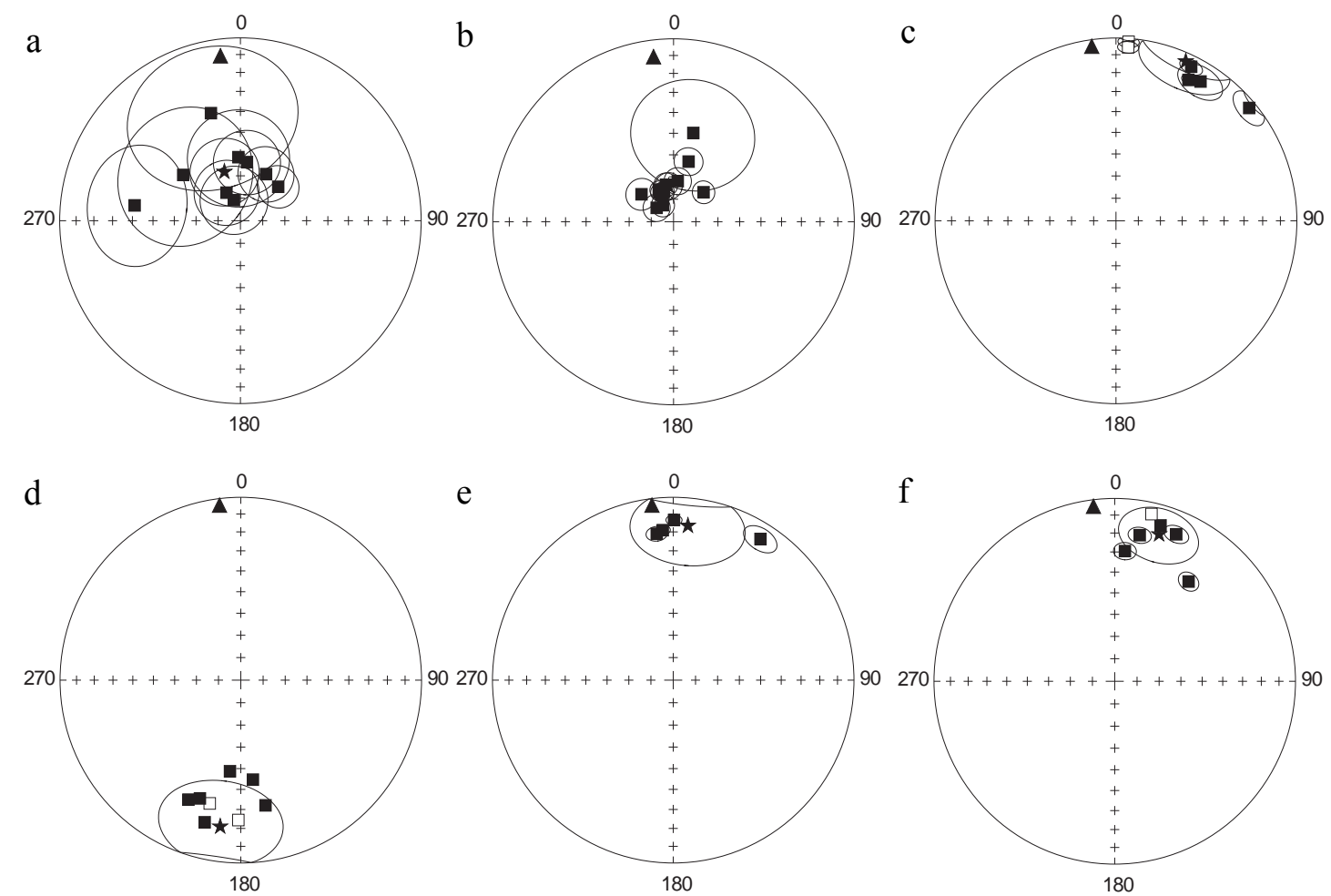

Fig. 8. Stereographic projections of individual trends and mean trend site, after dip correction, of Volta basin, in stratigraphic increasing order. $\star$ Fisher (1953) mean direction calculed after bring data in the same polarity:

$\boldsymbol{\Delta}$ Current geomagnetic field; $\square$ individual samples; a- Boumbouaka 1; b- Boumbouaka 2; c- Buipe; d- Koundjouaré ; e- Barkoissi 1; f- Barkoissi 2.

\section{DISCUSSION}

The data provided by magnetic mineralogy show that magnetization is carried by magnetite and hematite. One, two or three components were identified in the samples. The mean directions of the sites are located mainly in the NW and NE quadrants. Only the Koundjouare site occurs in the SW quadrant. The oldest formations of Boumbouaka 1 and 2 consist of fine to very fine sandstone, feldspathic with carbonate cement. They define VGP, Plon $=342.6^{\circ}$, Plat $=47.9^{\circ}, \mathrm{dp}=21^{\circ}$, $\mathrm{dm}=25.5^{\circ}$ and Plon $=355.2^{\circ}, \quad$ Plat $=39.9^{\circ}, \quad \mathrm{dp}=9.8^{\circ}$, $\mathrm{dm}=10.9^{\circ}$ respectively, yielding high palaeolatitude values of $49.6^{\circ} \mathrm{S}$ and $59.6^{\circ} \mathrm{S}$. These high palaeolatitudes are those that are attributed to the West African craton in models of the reconstruction of the supercontinent of Rodinia before $750 \mathrm{Ma}$. Such high palaeolatitudes found at Boumbouaka 1 and 2 well confirm the age between $993 \pm 65$ and $660 \pm 9 \mathrm{Ma}$ attributed to these two virtual geomagnetic poles. Nevertheless, the two VGP are close to those of the Adma Diorite, Plon $=344^{\circ}$, Plat $=34^{\circ}$, $\mathrm{dp}=16^{\circ}, \mathrm{dm}=17^{\circ}$, described in the Adrar of Iforas, dated between 620 and $590 \mathrm{Ma}$ (Morel, 1981).
The Buipe and Koundjouare sites, made of carbonate, and Barkoissi 1 and 2, made of silexites, are attributed to the triad of the middle Supergroup dated Marinoan to post-marinoan (Porter et al., 2004; Nedelec et al., 2007). The VGP of Buipe, Plon $=102.5^{\circ}$, Plat $=65.5^{\circ}, \mathrm{dp}=8.1^{\circ}$, $\mathrm{dm}=16.1^{\circ}$, Koundjouare in antipode, Plon $=159^{\circ}$, Plat $=67.6^{\circ}, \mathrm{dp}=12.8^{\circ}, \mathrm{dm}=24.3^{\circ}$ and Barkoissi 2, Plon $=94.6^{\circ}$, Plat $=73.2^{\circ}, \mathrm{dp}=7.9^{\circ}, \mathrm{dm}=15.3^{\circ}$ are grouped in the NW quadrant (Fig. 9). These sites define VGP's dated between $635 \mathrm{Ma}$, Marinoan age of the glaciomarine formation, and $600 \mathrm{Ma}$, age of Pan-African deformation that affects these formations. The palaeolatitudes obtained from these sites are situated between $2.6^{\circ} \mathrm{S}$ and $10.5^{\circ} \mathrm{S}$.These values are very different from those obtained at the two sites at Boumbouaka 1 and 2. They place the West African craton in subequatorial palaeolatitudes as was determined in the Gourma sub-basin (Boudzoumou et al., submitted). 


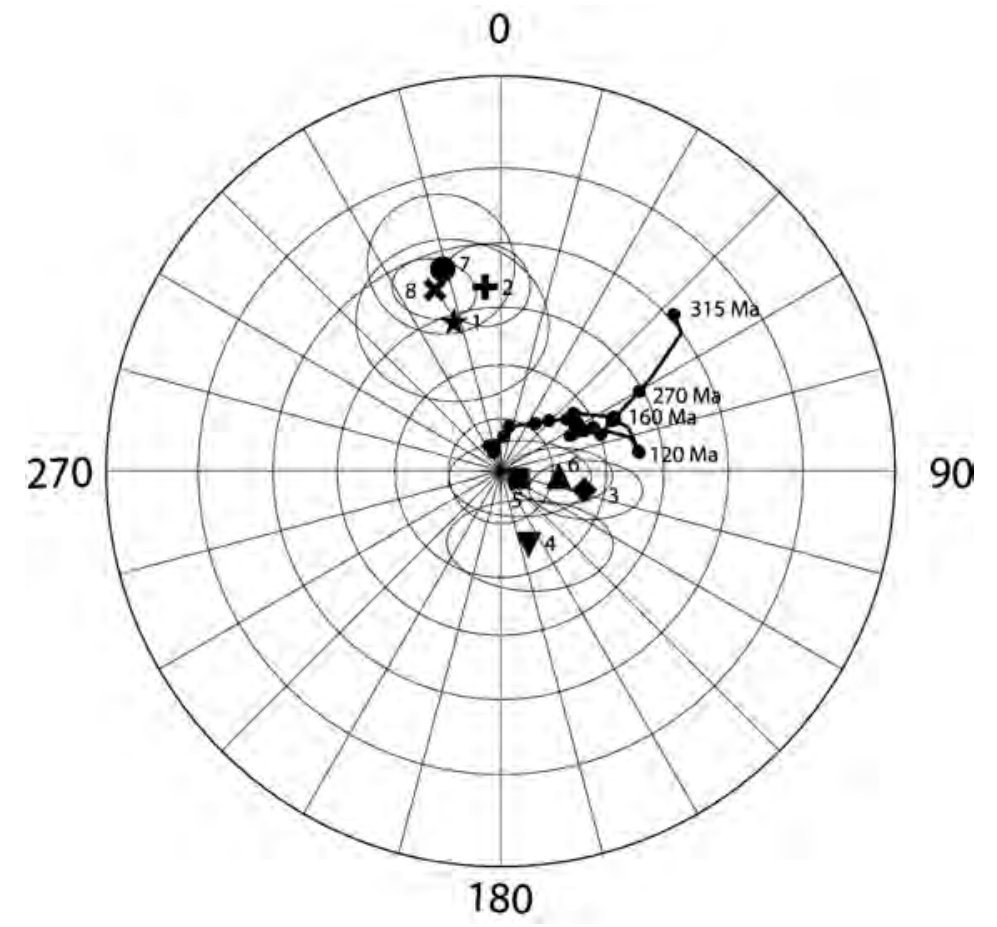

Fig. 9. VGP of Volta basin sites, Adma diorite of Adrar of Iforas and Puga cap carbonate of amazonian craton with Africa APWP (Besse and Courtillot, 2002). Lower hemisphere, Equiangular. Sites:1Boumbouaka 1; 2- Boumbouaka 2; 3- Buipe; 4- Koundjouare; 5- Barkoissi 1; 6- Barkoissi 2; 7- Adma diorite (Morel, 1981) ; 8- Puga cap carbonate B (Trindade et al., 2004).

\section{CONCLUSION}

The palaeomagnetic study of the Volta basin has improved the data base of the Neoproterozoic Formations of the West African craton. The magnetic mineralogy consists of magnetite and hematite, carriers of magnetization.

The mean direction obtained from the high temperature components allow the calculation of the VGP's at the different sites. The Boumbouaka sites 1 and 2 are made of fine to very fine grained sandstones and define a medium palaeopole of $\mathrm{Plon}=349.3^{\circ}, \quad$ Plat $=44.1^{\circ}$, $\mathrm{dp}=15.4^{\circ}, \mathrm{dm}=18.2^{\circ}$ dated between $993 \pm 65 \mathrm{Ma}$ and $660 \pm 9 \mathrm{Ma}$.

The associated palaeolatitude is $44.9^{\circ} \mathrm{S}$ which places the West African craton in a medium palaeolatitude as in the reconstruction models of the Rodinia supercontinent before its fragmentation (Meert and Torsvik, 2003). The Marinoan cap carbonate of Buipe and Koundjouare and the Barkoissi 2 silexites that overlie them give a medium palaeopole of Plon $=119.5^{\circ}, \quad$ Plat $=71.2^{\circ}, \quad \mathrm{dp}=9.7^{\circ}$, $\mathrm{dm}=18.6^{\circ}$ dated between $635 \mathrm{Ma}$ and $600 \mathrm{Ma}$. This palaeopole is associated with a palaeolatitude of $9.1^{\circ} \mathrm{S}$ which now places the West African craton at a low palaeolatitude in conformity with the Snowball Earth hypothesis which stipulates that all continental masses were located at low latitudes during the Marinoan epoch (Kirchvink, 1992; Hoffman et al., 1998; Hoffman and Schrag, 2002). The two palaeolatitudes of the two medium palaeopoles show a migration of the West
African craton from medium to low latitude toward the end of the Neoproterozoic.

\section{REFERENCES}

Affaton, P., 1990. Le bassin des Volta (Afrique de l'Ouest): une marge passive, d'âge protérozoïque supérieur, tectonisée au Panafricain (600 $\pm 50 \mathrm{Ma})$. Editions ORSTOM, Collection Etudes et Thèses, Paris. 500 p.

Amard, B., and Affaton, P., 1984. Découverte de Chuaria circularis (Acritarche) dans le Bassin des Volta (Haute-Volta et Bénin, Afrique de l'Ouest). Age protérozoïque terminal de la formation de la Pendjari et de la tillite sousjacente. Comptes Rendus Académie des Sciences Paris. 299, 975-980.

Besse, J., and Courtillot, V., 2002. Apparent and true polar wander and the geometry of the geomagnetic field in the last 200 millions years, J. geophys. Res., 107, 2300.

Boudzoumou, F., Vandamme, D., Affaton, P., and Gattacceca, J., (submitted). Neoproterozoic paleomagnetic poles in the Taoudéni basin (West Africa).

Clauer, N., 1976. Géochimie isotopique du strontium géochronologie de la couverture du craton 
ouest-africain. Sci. Géol. Mém. Strasbourg 45, $256 \mathrm{p}$.

Cogné, J.P., 2003. Paleomac: a Macintosh TM application for treating paleomagnetic data and making plate reconstruction. Geochem.

Geophys. Geosyst. 4 (1): 1007.

Deynoux, M., Affaton, P., Trompette, R., and Villeneuve, M., 2006. Pan-African tectonic evolution and glacial events registered in Neoproterozoic to Cambrian cratonic and foreland basins of West Africa. Journ. African Earth Sciences 46, 397426.

Fisher, R.A., 1953. Dispersion on a sphere. Proc. R. Soc. Lond. A 217, 295-305.

Hoffman, P.F., Kaufman, A.J., Halverson, G.P., and Schrag, D.P., 1998. A Neoproterozoic Snowball Earth. Science 281, 1342-1346.

Hoffman, P.F., and Schrag, D.P., 2002. The Snowball hypothesis: testing the limits of global change. Terra Nova 14, 129-155

Kirschvink, J.L., 1980. The least-squares lines and plane and the analysis of paleomagnetic data. Geophys. J. R. Astron. Soc. 62, 699-718.

Kirschvink, Z., 1992. Late Proterozoic low-latitude glaciations: the snowball Earth. In: Schopf, W. Klein, C. (Eds), the Proterozoic Biosphère. Cambridge University Press, $52 \mathrm{p}$.

Lowrie, W., 1990. Identification of ferromagnetic minerals in a rock by coercivity and unblocking temperature properties. Geophysical Research Letters $17, \mathrm{~N}^{\circ} .2,159-162$

Meert, J.G., and Torsvik, T.H. 2003. The making and unmaking of a Supecontinent: Rodinia revisited. Tectonophysics 375, 261-288.

Morel, P. 1981. Palaeomagnetism of a Pan-African diorite: a late Precambrian pole for westren Africa. Geophys. J. Roy. Astr. Soc. 65, 493-503.
Nédélec, A., Affaton, P., France-Lanord, C., Charrière, A., and Alvaro, J., 2007. Sedimentology and chemostratigraphy of the Bwipe Neoproterozoic cap dolostones (Ghana, Volta basin): a record of microbial activity in a peritidal environment. C.R. Geoscience 339.

Piper, J.D.A., and Darabi, M.H., 2005. Palaeomagnetic study of the (late Mesoproterozoic) Torridon group, NW Scotland: Age, magnetostratgraphy, tectonic setting and partial magnetic overprinting by Caledonian orogeny. Precambrian Research $142,45-81$.

Porter, S M., Knoll A.H., and Affaton P., 2004 Chemostratigraphy of Neoproterozoic cap carbonates from the Volta Basin, West Africa. Precambrian Research 130, 99-112

Raposo, M.I.B., D'Agrella-Filho, M.S., and Siqueira, R., 2003. The effect of magnetic anisotropy on paleomagnetic directions in high-grade metamorphic rocks from the Juiz de Fora Complex, SE Brazil. Earth and Planetary Sciences Letters 209, 131-147.

Raposo, M.I., McReath, I., and D'Agrella-Filho, M.S., 2006. Magnetic fabrics, rock magnetism, cathodoluminescence and petrography of apparently undeformed Bambui carbonates from Sao Francisco Basin (Minas Gerais State, SE Brazil): An integrated study. Tectonophysics 418, 111-130.

Trindade, R. I. F., Font, E., D'Agrella-Filho, M. S., Nogueira, A. C. R., and Riccomini, C., 2003. Lowlatitude and multiple geomagnetic reversals in the Neoproterozoic Puga cap carbonate, Amazon craton, Terra Nova 15, 441-446

Zijderveld, J.D.A., 1967. AC demagnetization of rocks: Analysis of result. In: Collinson D.W., Runcorn S.K., and Creer K.M. (Eds.), Methods in Paleomagnetism. Elsevier, New York. 